\title{
Persistent Activation of Protein Kinase C during the Development of Long-Term Facilitation in Aplysia
}

\author{
Wayne S. Sossin, ${ }^{1-3}$ Todd C. Sacktor, ${ }^{1,4}$ and James H. Schwartz ${ }^{1}$ \\ ${ }^{1}$ Center for Neurobiology and Behavior \\ Columbia University College of Physicians and Surgeons \\ New York, New York 10032
}

\begin{abstract}
We investigated activation of the two major neuronal protein kinase C (PKC) isoforms in Aplysia, $\mathrm{Ca}^{2+}$-activated $\mathrm{Apl} \mathrm{I}$ and $\mathrm{Ca}^{2+}$-independent Apl II, during the induction and maintenance of behavioral sensitization of Aplysia defensive reflexes. Activation of PKC occurred during the training stimulus and persisted for at least 2 hr thereafter but was not maintained for 24 $h r$. The persistent activation required protein synthesis and was blocked by cyproheptidine, an agent that also blocked the initial activation of PKC. Persistent activation involved both an increase in membrane-associated Apl I and an increase in an autonomous kinase activity that may be related to a post-translational modification of Apl II. These results are consistent with the hypothesis that in addition to its role in producing the presynaptic facilitation of mechanosensorymotor neuron synapses that underlie short-term facilitation, PKC is needed for maintaining synaptic changes in an intermediate period that precedes the modifications accompanying consolidation of memory.
\end{abstract}

\footnotetext{
${ }^{2}$ Corresponding author.

Present addresses: ${ }^{3}$ Department of Neurology and Neurosurgery, McGill University, Montreal Neurological Institute, Montreal, Quebec, Canada H3A-2B4; ${ }^{4}$ Department of Pharmacology and Department of Neurology, State University of New York, Brooklyn, Brooklyn, New York 1203-298 USA.
}

\section{Introduction}

Protein kinases are important modulators of synaptic transmission (Byrne et al. 1991; Catterall et al. 1991; Swope et al. 1992; Greengard et al. 1993). By phosphorylating neuronal proteins, kinases produce both short- and long-term changes in the strength of the connections between neurons and their targets. Persistent activation of protein kinases at the synapse may constitute a molecular record of previous synaptic events that serves as an intermediate form of memory between short-term actions that are dependent on transient changes in concentration of second messengers and long-term structural changes at the synapse (Lisman 1985; Schwartz and Greenberg 1987; Schwartz 1993). We are therefore interested in understanding how protein kinases are regulated in neurons, and how persistent protein kinase activity is initiated and maintained.

Protein kinase C (PKC) is a family of multifunctional protein kinases (Nishizuka 1992; Dekker and Parker 1994) with an important role in regulating synaptic function. In neurons, PKCs are physiologically activated during several learning paradigms in vertebrates (Akers et al. 1986; Bank et al. 1989; Burchuladze et al. 1990; Klann et al. 1991; Sacktor et al. 1993; Sunayashiki et al. 1993) and invertebrates (Sacktor and Schwartz 1990, McPhie et al. 1993). Furthermore, activation of PKCs by pharmacological agents, such as phorbol esters, leads to an increase in synaptic strength seen in many different nervous systems, from invertebrates to mammals (Farley and Auerbach 1986; Malenka et al. 1986, 1987; Braha et al. 1990; Finch and Jackson 1990; Sugita et al. 1992).

There is also evidence that persistent activation of PKC is important for maintaining synaptic modifications. Increases in PKC activity can last

LEARNING \& MEMORY 1:189-202 @ 1994 by Cold Spring Harbor Laboratory Press ISSN1072-0502/94 \$5.00

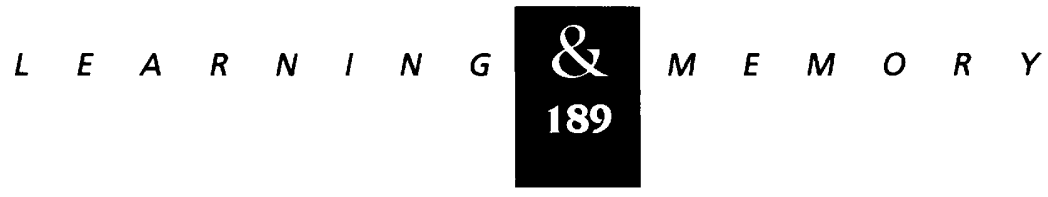


long after the initial training stimulus has ended (Akers et al. 1986; Bank et al. 1989; Klann et al. 1991; Olds and Alkon 1991; Sacktor et al. 1993). In addition, inhibitors of PKC not only can block the immediate synaptic changes (Lovinger et al. 1987; Malenka et al. 1989; Braha et al. 1990; Farley and Schuman 1991; Sugita et al. 1992; Ghirardi et al. 1992) but also the maintenance of these changes (Malinow et al. 1988; Farley and Schuman 1991; Wang and Feng 1992). Molecular mechanisms causing persistent PKC activity may be changes in regulators of the kinase or post-translational modifications of the enzyme itself that make it less dependent on regulators. Recent evidence suggests that the enzyme molecule is modified during the maintenance phase of long-term potentiation of hippocampal CA1 neurons by phosphorylation of $\mathrm{Ca}^{2+}$-activated PKCs (Klann et al. 1993) and formation of a constitutively active or autonomous kinase by specific proteolytic removal of the regulatory region of the $\mathrm{Ca}^{2+}$-independent $\zeta$ isoform (Sacktor et al. 1993).

One impediment to examining the role of PKC in synaptic plasticity is that the multiplicity of isoforms present in the mammalian brain makes it difficult to assign specific functions to any one isoform (e.g., see Dekker and Parker 1994). In the marine mollusk Aplysia, we have shown that all of the PKC activity in neurons can be accounted for by two isoforms, the $\mathrm{Ca}^{2+}$-activated Apl I and the $\mathrm{Ca}^{2+}$-independent Apl II (Kruger et al. 1991; Sossin et al. 1993), and we have developed a kinase assay that allows the two isoforms to be measured independently (Sossin and Schwartz 1992). This makes Aplysia an attractive organism for studying the physiological roles of specific PKC isoforms.

In Aplysia, behavioral sensitization of the animal leads to an increase in the strength of mechanosensory-motor connections that can last from minutes to days (Frost et al. 1985; Scholtz and Byrne 1987). Originally, cAMP-dependent protein kinase (PKA) was shown to be involved in both short- and long-term increases in synaptic strength (Kandel and Schwartz 1982; Schacher et al. 1988; Sweatt and Kandel 1989). Recently, a role for PKC in short-term sensitization of sensory neurons has also been demonstrated. 5-HT, a facilitating neurotransmitter that mediates sensitization, activates PKC (Sacktor and Schwartz 1990; Sossin and Schwartz 1992). Some of the short-term changes mediated by 5 -HT are mimicked by phorbol esters and are blocked by inhibitors of PKC (Braha et al. 1990, 1993; Ghirardi et al. 1992; Sugita et al.
1992). Little is known, however, about the activation of PKC in long-term sensitization. To address this issue, we examined PKC activity after treatments that stimulate long-term changes in synaptic efficacy in Aplysia.

\section{Materials and Methods}

Aplysia californica (70-100 grams; Aplysia research facility at the University of Miami, FL) were housed individually for 1-2 weeks before training. Animals that inked when gently handled or that did not eat regularly were excluded from these studies. Unless stated otherwise, all chemicals are from Sigma (St. Louis, MO).

\section{BEHAVIORAL SENSITIZATION}

Each training episode consisted of 10 shocks along one side of the animal. The long-term sensitization protocol consisted of four training episodes with an interval of $30 \mathrm{~min}$ between each episode (Scholtz and Byrne 1987). These unilateral stimulations result in sensitization of one side of the animal, allowing the unshocked side to be used as a paired control (Scholtz and Byrne 1987). Equal numbers of animals were shocked on the left and right sides to avoid the effects of any possible differences between the two sides. To examine the efficacy of behavioral sensitization, we measured the duration of siphon withdrawal after stimulation of the body wall with a jet of water. Each side was tested twice prior to training, and twice $24 \mathrm{hr}$ after the training.

\section{ISOLATION OF PLEURAL PEDAL GANGLIA}

After training experiments, animals were first placed in a bath of isotonic $\mathbf{M g C l}_{2}$ /artificial seawater $(1: 1, \mathrm{vol} / \mathrm{vol})$ at the end of the experimental period and then anesthetized with an injection of isotonic $\mathrm{MgCl}_{2}$. Pleural-pedal ganglia were isolated rapidly from the animal and pinned to silicone plastic (Sylgard, Dow Corning, Midland, MI) in ice-cold dissecting seawater containing high $\mathrm{Mg}^{2+}$ and low $\mathrm{Ca}^{2+}[230 \mathrm{~mm} \mathrm{NaCl}, 220 \mathrm{~mm}$ $\mathrm{MgCl}_{2}, 1 \mathrm{mM} \mathrm{CaCl}, 10 \mathrm{~mm} \mathrm{KCl}, 10 \mathrm{~mm}$ HEPES, $0.2 \times$ minimal essential medium (MEM) amino acids (GIBCO BRL, Gaithersburg, MD), 0.2 $\times$ MEM

$$
\begin{array}{lllllllllllllllll}
\hline & E & A & R & N & I & N & G & \mathbf{Q}_{100} & M & E & M & O & R & Y
\end{array}
$$


nonessential amino acids, $0.5 \times$ MEM vitamin solution, and $10 \mathrm{~mm}$ glutamine added just before use (final pH 7.8; Eisenstadt et al. 1973)].

Each pleural ganglion contains a cluster of 200 pleural sensory cell bodies with terminals in the pedal ganglion. These ganglia are connected by the short pleural-pedal connective. The pair of ganglia are symmetrical, and in all experiments the pair on one side of the animal is used as a control for the pair on the other. Kinase activity is measured in the entire pleural-pedal ganglia. Although we have shown previously that 5 -HT can activate PKC specifically in the sensory cell cluster, with approximately twice the increase seen in the whole ganglia (Sacktor and Schwartz 1990), the number of clusters required for each PKC determination, particularly for the subtractive assay (see below), makes isolation of sensory cells impractical for the large number of determinations required for time-course and pharmacological experiments. In addition, other effects of long-term sensitization can be seen in measurements of the whole pleural ganglia (Kuhl et al. 1992).

For experiments with isolated ganglia, nervous tissue was placed in normal seawater [same as dissecting seawater but with $460 \mathrm{~mm} \mathrm{NaCl}, 11$ $\mathrm{mm} \mathrm{CaCl} 2,55 \mathrm{~mm} \mathrm{MgCl}_{2}$ (Eisenstadt et al. 1973)] after the ganglia had been dissected from naive animals, and the ganglia were incubated at $15^{\circ} \mathrm{C}$ for $30 \mathrm{~min}$. The ganglia were exposed to the media by slitting the connective tissue sheath, washed in normal seawater and incubated for at least another $30 \mathrm{~min}$ at $15^{\circ} \mathrm{C}$ before application of pharmacological agents or 5-HT.

\section{PREPARATION OF EXTRACTS}

Ganglia were washed twice with ice-cold dissecting seawater and twice with ice-cold $50 \mathrm{~mm}$ Tris- $\mathrm{HCl}$ (pH 7.5), $10 \mathrm{~mm} \mathrm{MgCl}_{2}, 1 \mathrm{~mm}$ EGTA, 0.1 mM phenylmethylsulfonyl fluoride, $5 \mathrm{~mm} 2$-mercaptoethanol, $20 \mu \mathrm{g} / \mathrm{ml}$ of aprotinin, $5 \mathrm{~mm}$ benzamidine, and $0.1 \mathrm{~mm}$ leupeptin (homogenization buffer; Sacktor and Schwartz 1990) The neuronal components were then removed (Schwartz and Swanson 1987) and homogenized in $400 \mu$ of the buffer in glass-glass homogenizers (Micro-metric, Tampa, FL). The homogenates were first centrifuged at $1,000 \mathrm{~g}$ for $1 \mathrm{~min}$ to remove unbroken cells and debris, and the resulting supernatant was centrifuged for $30 \mathrm{~min}$ at $100,000 \mathrm{~g}$ to isolate supernatant and particulate fractions.

\section{SUBTRACTIVE ASSAY}

The assay to measure Apl I and Apl II activity independently is essentially the same as described (Sossin and Schwartz 1992). The assay is based on the binding of the $\mathrm{Ca}^{2+}$-activated PKCs, Apl I, but not the $\mathrm{Ca}^{2+}$-independent PKC, Apl II, to lipid vesicles in the presence of $\mathrm{Ca}^{2+}$ ions, allowing the selective removal of Apl I by sedimentation of the vesicles. Recently, the selectivity of this assay was confirmed by showing the removal of Apl I, but not Apl II, after separation of the kinases by hydroxyapatite chromatography (Sossin et al. 1993).

The particulate fraction was suspended in $\mathbf{1 5 0}$ $\mu l$ of homogenization buffer by 10 passes through a 25-gauge needle. To remove PKC from the membrane, $72 \mu \mathrm{l}$ of the suspended particulate fraction was added to $8 \mu \mathrm{l}$ of $10 \%$ octyl- $\beta$-glucoside (Pierce, Rockford, IL; final concentration $1 \%$ octyl- $\beta$-glucoside) and incubated for $20 \mathrm{~min}$ at $4^{\circ} \mathrm{C}$. The rest of the particulate fraction was saved for protein determination. To measure $\mathrm{Ca}^{2+}$-independent PKC activity, $\mathrm{Ca}^{2+}$-activated PKCs were removed by sedimentation: Twenty microliters of the suspended particulate fraction was diluted fivefold in homogenization buffer with lipid vesicles $[125 \mu \mathrm{g} / \mathrm{ml}$ of a mixture of dioleoyl phosphatidylserine (Avanti Polar Lipids, Alabaster, AL) and dioleoyl phosphatidylcholine (Princeton Lipids, Princeton, NJ) $(9: 1, w t / w t)$, hereafter referred to as PS] and $\mathrm{Ca}^{2+}$ (125 $\mu \mathrm{M}$ final concentration; $1.125 \mathrm{mM} \mathrm{Ca}^{2+}$ with $1 \mathrm{~mm}$ EGTA in the buffer). After $5 \mathrm{~min}$ at $20^{\circ} \mathrm{C}$, the samples were centrifuged at $100,000 \mathrm{~g}$ for $30 \mathrm{~min}$ to sediment the PS vesicles. To measure total PKC activity, $20 \mu$ l of the suspended particulate fraction was diluted fivefold with just homogenization buffer. Fifty microliters of the resulting supernatants was then diluted threefold in homogenization buffer before being assayed for kinase activity. $\mathrm{Ca}^{2+}$-activated PKC activity is measured as the difference between total PKC activity and $\mathrm{Ca}^{2+}$-independent activity. For assays using histone phosphorylation, the particulate fraction was suspended fivefold in homogenization buffer with $0.05 \%$ Triton X-100 and immediately used for the PKC assay (Sacktor and Schwartz 1990).

\section{PKC ASSAY}

Kinase activity was assayed either as described (Sacktor and Schwartz 1990) for histone phospho-

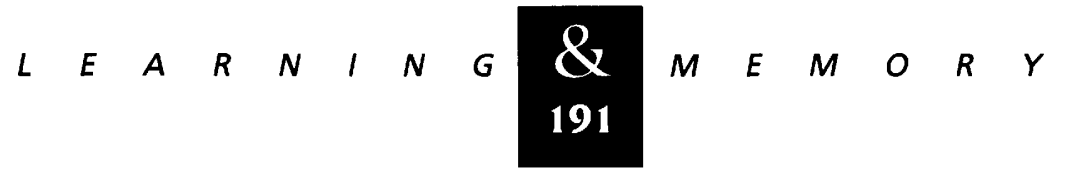


rylation or with the following modifications for the subtractive assay. The reaction mixture (30 $\mu l)$ contained $50 \mathrm{~mm}$ Tris- $\mathrm{HCl}(\mathrm{pH} 7.5), 10 \mathrm{~mm}$ $\mathrm{MgCl}_{2}, 0.1 \mathrm{mg} / \mathrm{ml}$ of cAMP-dependent protein kinase inhibitor (Walsh), $10 \mathrm{~mm}$ EGTA, and $600 \mathrm{~nm}$ AE-pep, (LNRRRGSMRRRVHQVNGH), a synthetic peptide based on the pseudosubstrate peptide of Apl II shown to be phosphorylated well by both Apl I and Apl II (Sossin and Schwartz 1992; Sossin et al. 1993) in the presence or absence of $50 \mu \mathrm{g}$ / $\mathrm{ml}$ of PS, and $20 \mathrm{~nm} \mathrm{12-O-tetradecanoyl-phorbol-}$ 13-acetate (TPA). After addition of $10 \mu \mathrm{l}$ of extract ( $\mathrm{Ca}^{2+}$-independent PKC or total PKC), the reaction was started with $10 \mu l$ of $\left[\gamma_{-}{ }^{32} \mathrm{P}\right] \mathrm{ATP}$ (New England Nuclear, Boston, MA) $(1 \mu \mathrm{Ci}, 50 \mu \mathrm{M}$ final concentration). After $30 \mathrm{~min}$ at $20^{\circ} \mathrm{C}, 40 \mu \mathrm{l}$ of the $50-\mu l$ reaction mixture was spotted onto a Whatman phosphocellulose paper disk, which was washed in $100 \mathrm{ml}$ of $5 \%(\mathrm{wt} / \mathrm{vol})$ ATP. The disks were then rinsed four times for 5 min with $0.425 \%$ ( vol/vol) phosphoric acid, and radioactivity was determined by scintillation. Each value is the average of duplicate determinations.

PKC activity is defined as the difference in phosphorylation between that obtained in the presence or absence of PKC activators (PS and TPA). Autonomous kinase activity is the amount of phosphorylation obtained without PKC activators but in the presence of EGTA and the specific inhibitor of the cAMP-dependent kinase. Averages for control particulate activities are $\mathrm{Ca}^{2+}$-activated PKC activity, $172 \pm 85 \mathrm{pmoles} / \mathrm{min}$ per $\mathrm{mg}$; $\mathrm{Ca}^{2+}$-independent PKC activity, $157 \pm 66$ pmoles/ min per $\mathrm{mg}$; autonomous kinase activity, 107 \pm 45 pmoles/min per mg; S.D.; $\boldsymbol{n}=189$.

\section{IMMUNOBLOTS}

To obtain a signal from particulate fractions, we combined two or three pleural-pedal ganglia. The separation of supernatant and particulate fractions is described above. After suspension of the particulate fraction in homogenization buffer, a sample was removed for protein determination and sample buffer was added to the remainder and heated at $90^{\circ} \mathrm{C}$ for $7 \mathrm{~min}$. Membrane and supernatant protein $(15-20 \mu \mathrm{g})$ was electrophoresed by SDS-PAGE and then transferred to nitrocellulose paper as described (Kruger et al. 1991). We detected Apl I and Apl II immunoreactivity using chemoluminescence (Amersham, Arlington
Heights, IL) with $10 \mu \mathrm{g} / \mathrm{ml}$ of affinity purified antiApl II (Kruger et al. 1991), $10 \mu \mathrm{g} / \mathrm{ml}$ of polyclonal anti-Apl I (Sossin et al. 1993), and 1:1000 goat anti-rabbit coupled to horseradish peroxidase (Pierce) The samples were quantitated using a Hoeffer (San Fransisco, CA) GS 300 scanning densitometer.

\section{IMMUNOPRECIPITATIONS}

The data were obtained from the immunoprecipitation experiments as described (Sossin et al. 1993).

\section{Results}

\section{ACTIVATION OF PKCs}

To begin elucidating the role of PKCs in longterm sensitization in Aplysia, we measured changes in PKC activity during the induction of long-term facilitation of sensory-to-motor synapses. We measured PKC activation as an increase in kinase activity in the particulate fraction, as activated PKC is presumed to translocate to the membrane (Thomas et al. 1987; Nishizuka 1992). These measurements reveal just one possible way that PKCs are activated in vivo, however, because specific isoforms of PKC may also translocate to cytoskeleton or nucleus, or not translocate at all after activation (Heidenrich et al. 1990; Kiley and Jaken 1990; Leach and Raben 1993).

We used two protocols to activate the kinase: behavioral sensitization (Scholtz and Byrne 1987) and prolonged application of 5-HT to isolated ganglia (Barzilai et al. 1989). PKC isozymes were activated in three distinct phases during the development of long-term facilitation as determined by our subtractive assay (see Materials and Methods). In the first phase, corresponding to short-term facilitation, Apl I was activated but Apl II was not (Fig. 1; Sossin and Schwartz 1992). This activation does not persist, even in the presence of continued stimulation (Fig. 1). In the second phase, which may be described as transitional, both Apl I and Apl II were activated $\sim 2-2.5 \mathrm{hr}$ after the beginning of the training protocol (Fig. 1). This result suggests that both isoforms of PKC become active as long-term facilitation develops. In the third phase, corresponding to intermediate facilitation, Apl I remained persistently activated for as

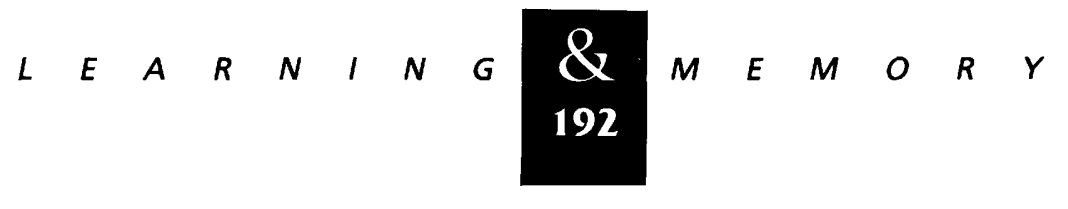




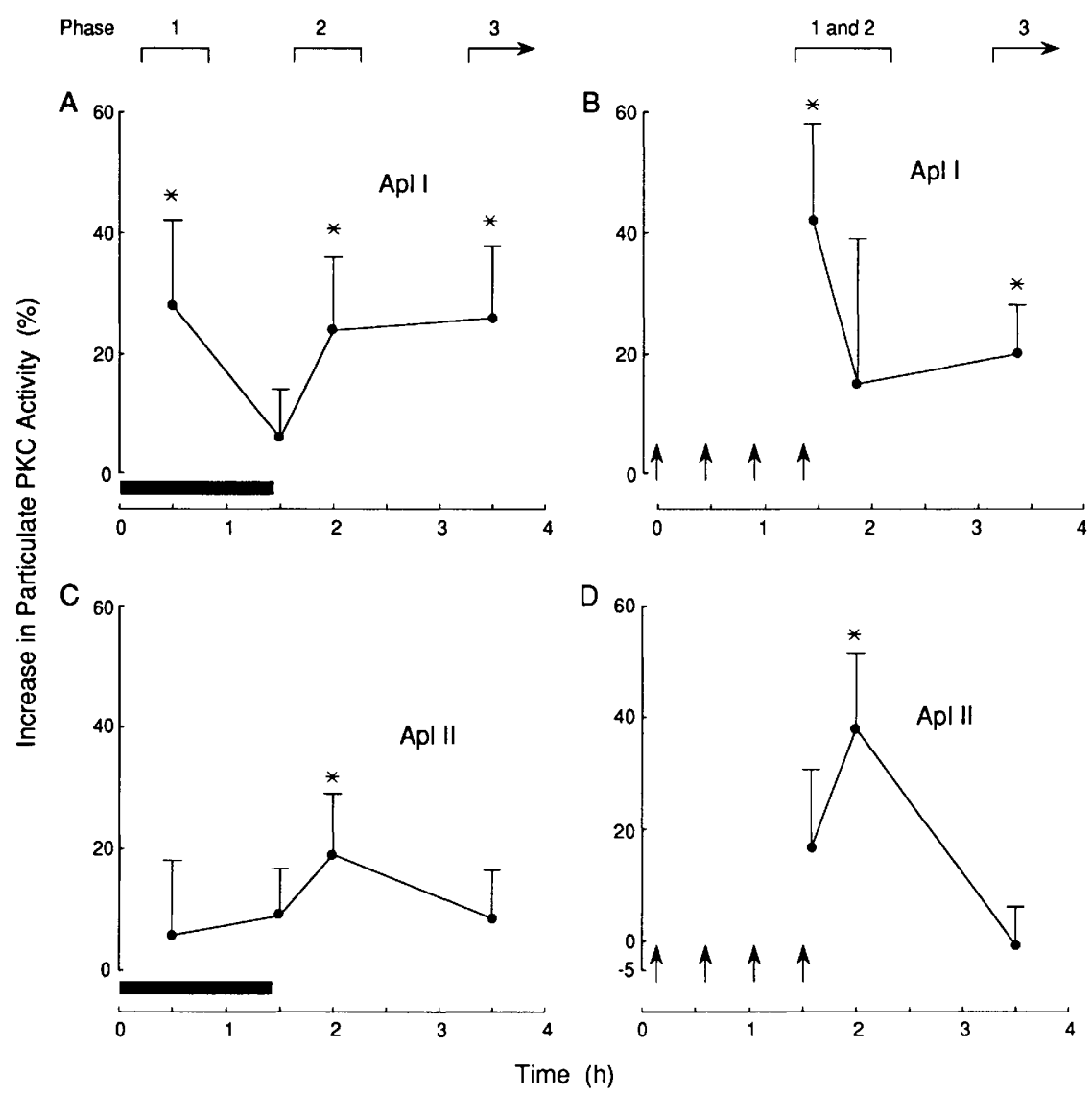

Figure 1: PKCs are activated in three phases during long-term facilitation. Experiments involved either treatment of intact isolated pleural-pedal ganglia with 5-HT $(A, C)$ or training for behavioral sensitization of animals followed at various time intervals later by dissection of pleural-pedal ganglia $(B, D)$. Both training protocols allowed the unstimulated pleural-pedal ganglion to be used as a control from the same animal. Activation of PKC was measured as the percent change in particulate kinase activity between stimulated and control sides using a subtractive enzyme assay that measures independently the two major PKCs in Aplysia nervous tissue, Apl I $(A, B)$ and Apl II (C,D) (Sossin and Schwartz 1992; see Materials and Methods). Horizontal bars $(A, C)$ represent the time during which the isolated ganglia were exposed to 5-HT $(20 \mu \mathrm{M})$. Vertical arrows $(B, D)$ show the time of training episodes. Asterisks $\left(^{*}\right)$ indicate measurements where a comparison between the experimental and control ganglia (paired $t$-test) reached a significance value of $P<0.05$. The phases indicated by the brackets at the top are described in the text. In experiments with behavioral sensitization, short-term sensitization from the last training episode is occurring with the development of long-term sensitization in the early part of phase 2. Values are mean \pm S.E.M.; $n=8-16$ independent determinations.

long as $3.5 \mathrm{hr}$ after the initial stimulus, whereas Apl II returned to its initial level (Fig. 1). This time course of Apl I activation during training was also seen in an independent series of experiments using histone phosphorylation as an assay for PKC (data not shown). Histone phosphorylation measures mainly Apl I, because Apl II phosphorylates histone poorly (Sossin and Schwartz 1992).

We then asked whether the different phases of Apl I activation could be dissociated pharmacologically. Anisomycin, an inhibitor of protein synthesis, blocked the later activation of Apl I (third phase) but did not affect its short-term activation (first phase) (Fig. 2). This effect is similar to the actions of anisomycin on the biophysical changes observed at sensory-to-motor synapses, where the drug dissociates physiological responses by blocking long-term facilitation measured after $24 \mathrm{hr}$ without affecting short-term facilitation (Montarolo et al. 1986). Cyproheptidine, a 5-HT receptor antagonist, also dissociates short- and longterm processes but in a reciprocal fashion to anisomycin, blocking short- but not long-term facilitation (Emptage and Carew 1993). We find that cyproheptidine blocked both the short-term and the later phases of Apl I activation (Fig. 2), 
Sossin et al.

A Short-term (Phase 1)

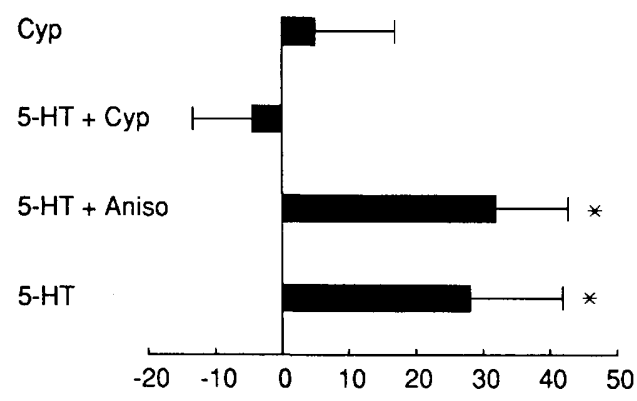

B Intermediate (Phase 3)

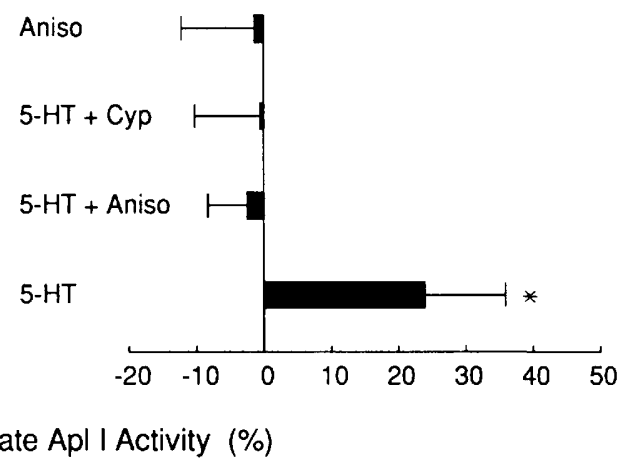

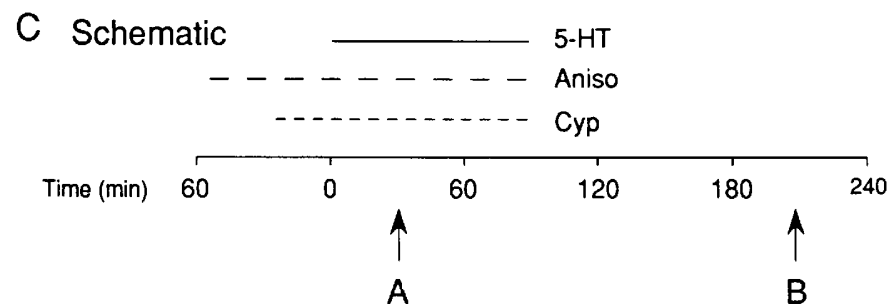

Figure 2: Short- and long-term activation of Apl I can be dissociated. Isolated pleural-pedal ganglia were used in all experiments. Activation of PKC was measured as the percent change in particulate kinase activity between stimulated and control ganglia using a subtractive assay that measures Apl I and Apl II independently (Sossin and Schwartz 1992; see Materials and Methods). Ganglia were assayed for PKC activation after a 30-min exposure to 5-HT (A) or $120 \mathrm{~min}$ after a 90-min application of 5-HT (B) with no drug (5-HT), or in the presence of $20 \mu \mathrm{M}$ anisomycin (5-HT + Aniso) or $200 \mu \mathrm{M}$ cyproheptidine $(5-\mathrm{HT}+\mathrm{Cyp})$. Drugs were applied at the times shown in the schematic $(C)$. In each of these experiments, the only difference between control and stimulated ganglia was the presence of 5-HT (i.e., anisomycin vs. anisomycin + 5HT). The drugs alone had no effect on the amount of Apl I activity [(A), $200 \mu \mathrm{M}$ cyproheptidine (Cyp); (B), $20 \mu \mathrm{M}$ anisomycin (Aniso)]. The values for $5-\mathrm{HT}$ alone $(5-\mathrm{HT})$ are the same as those shown in Fig. 1. Asterisks $\left(^{*}\right)$ indicate measurements in which a comparison between the experimental and control ganglia (paired t-test) reached a significance value of $P<0.05$. We also did comparisons between exposure to $5-\mathrm{HT}$ and exposure to $5-\mathrm{HT}+$ drug. The difference between $5-\mathrm{HT}$ and $5-\mathrm{HT}+$ cyproheptidine after $30 \mathrm{~min}(A)$ and the difference between $5-\mathrm{HT}$ and $5-\mathrm{HT}+$ cyproheptidine or between $5-\mathrm{HT}$ and $5-\mathrm{HT}+$ anisomycin after $90+120 \mathrm{~min}(B)$ reached a significance value of $P<0.05$ (unpaired $t$-test). Activation of Apl II was also monitored in these experiments (see Materials and Methods), but comparison between experimental and control ganglia did not reach significance values of $P<0.05$ except for the treatment with anisomycin alone, where the increase in particulate Apl II activity in the experimental ganglia is significant $(23 \pm 12 \%$ increase, $P<0.05$ paired $t$-test). All values are mean \pm S.E.M.; $n=8-14$.

suggesting that the initial phase of Apl I activation, or another process blocked by cyproheptidine is required for the later phase to occur.

The observation that cyproheptidine blocks Apl I activation but not the facilitation measured $24 \mathrm{hr}$ later suggests that PKC activation is not needed to establish long-term sensitization measured after $24 \mathrm{hr}$. Consistent with this idea, we observed that PKCs are not activated $24 \mathrm{hr}$ after behavioral sensitization (Table 1). Furthermore, there was no correlation between the activation of Apl I and the behavioral change seen after $24 \mathrm{hr}$.
These results argue that persistent activation of Apl I is not required at this stage of the long-term behavioral change. There is evidence that other 5-HT-mediated biochemical changes such as persistent activation of PKA (Ghirardi et al. 1994) and the activation of the ApC/EBP transcription factor (Alberini et al. 1994) also are no longer required after consolidation of the synaptic memory. We propose that persistent activation of Apl $I$ is needed for the intermediate stages of facilitation, possibly participating in maintaining facilitation during the transition to more permanent modifi-

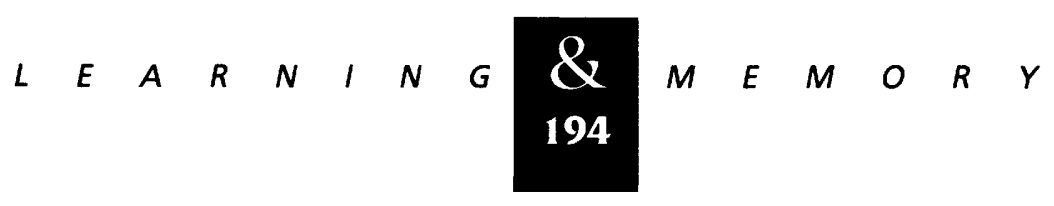


Table 1: Lack of correlation between Apl I activation and the duration of siphon withdrawal measured $24 \mathrm{~h}$ after training

\begin{tabular}{lc}
\hline Measurement & Change after $24 \mathrm{hr} \mathrm{( \% )}$ \\
\hline $\begin{array}{l}\text { Particulate Apl I } \\
\text { activity }\end{array}$ & $1.8 \pm 18$ \\
$\begin{array}{l}\text { Particulate Apl II } \\
\text { activity }\end{array}$ & $-4.6 \pm 9$ \\
$\begin{array}{l}\text { Duration of siphon } \\
\text { withdrawal }\end{array}$ & $99 \pm 21$ \\
\hline
\end{tabular}

Animals were trained for long-term behavioral sensitization as described in Fig. 1. A day later, the pleuralpedal ganglia were removed for dissection after the duration of siphon withdrawal was measured as described in Materials and Methods. There was no significant correlation between the two measures $\left(r^{2}=0.3\right)$. The actual values for siphon withdrawal in seconds are trained side (before training) $3.9 \pm 0.3$, (after training) $7.4 \pm$ 0.7 ; untrained side (before training) $3.6 \pm 0.3$, (after training) $2.5 \pm 0.1$. Both the increase on the trained side and the decrease on the untrained side are significant at $P<0.01$ (paired $t$-test).

cations of synaptic strength (Bailey and Kandel 1993; Alberini et al. 1994).

\section{MECHANISMS OF PRODUCING PERSISTENT PKC ACTIVATION}

Prolonged activation of PKC can be explained in two ways. First, changes in gene expression can lead to alterations in the balance between kinase activators and inhibitors, causing a persistent increase in the proportion of PKC associated with the membrane. Second, changes in gene expression can modify the enzyme molecule making it autonomous, no longer requiring exogenous activators after the original stimulus is removed.

We found evidence that both of these processes participate in the activation of PKC during the development of long-term facilitation in Aply. sia. Consistent with the first explanation in which there is a change in the balance between PKC activators and inhibitors, we observed that increases in PKC activity are associated with increases in the proportion of particulate PKC as measured by immunoblotting (Figs. 3 and 4). We did not observe significant increases in the total amount of PKC, as there were no changes observed in the amount of supernatant PKC. This argues against the possibility that the persistent increase of PKC particulate activity results from an increase in synthesis of
PKC. We also found evidence for the second mechanism. There was an increase in constitutive kinase activity (the amount of phosphorylation of the PKC pseudosubstrate-based peptide measured without PKC activators). This increase required protocols that produce long-term sensitization and was blocked by both anisomycin and cyproheptidine (Fig 5).

For several reasons it is likely that the constitutive or autonomous phosphorylation observed results from activating a PKC rather than another kinase. The substrate peptide is used at concentra-

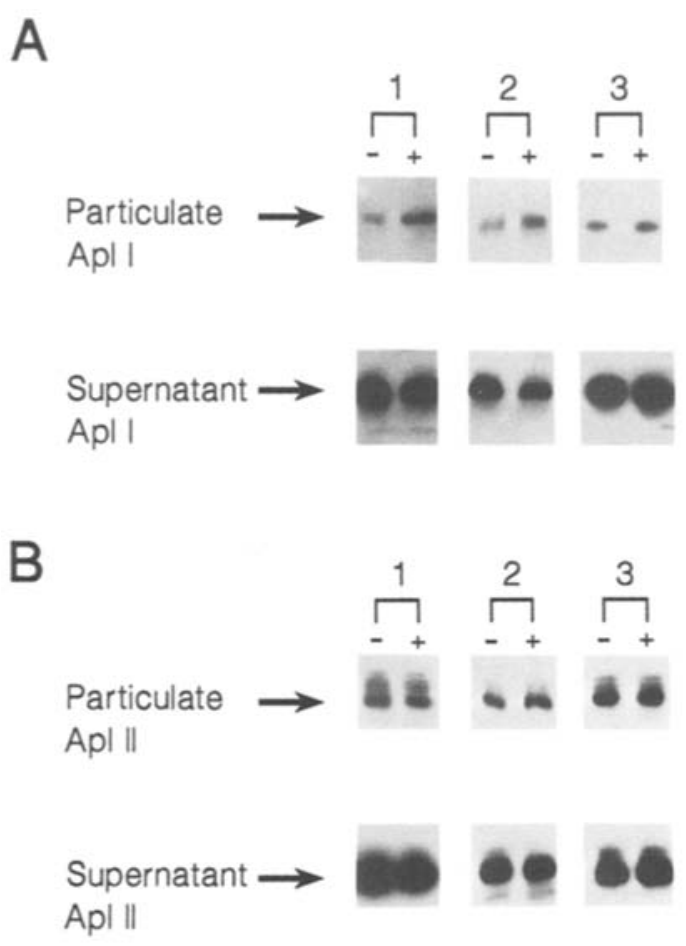

Figure 3: Apl I associated with the membrane increases after training for long-term sensitization. Isolated pleural-pedal ganglia were exposed to $20 \mu \mathrm{M} 5-\mathrm{HT}(+)$ or normal seawater (-) for $30 \mathrm{~min}(1), 90 \mathrm{~min}$ with a 30 -min wash (2), or 90 min with a 2 -hr wash (3), the times corresponding to phases 1,2 , and 3 as described in Fig. 1, and then extracted. The supernatant and particulate fractions were separated by centrifugation and assayed by immunoblotting (see Materials and Methods) using antibodies to Apl I (A) or Apl II (B). There is an increase in $A p l ~ I$ immunoreactivity in the particulate fraction, with no increase in the supernatant fraction, suggesting that the percentage of particulate $\mathrm{Apl} I$ is persistently increased by stimuli that result in long-term facilitation. In immunoblots using antibodies to Apl II, we observe increases in the particulate fraction only during phase 2.

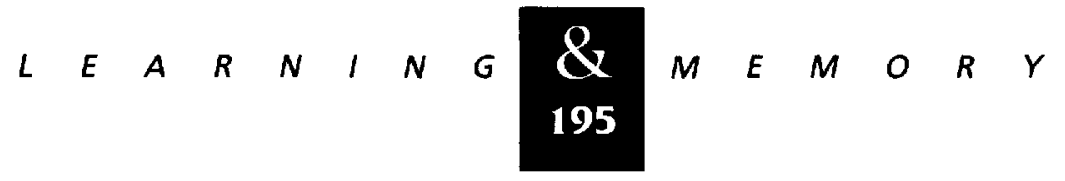


Sossin et al.

A

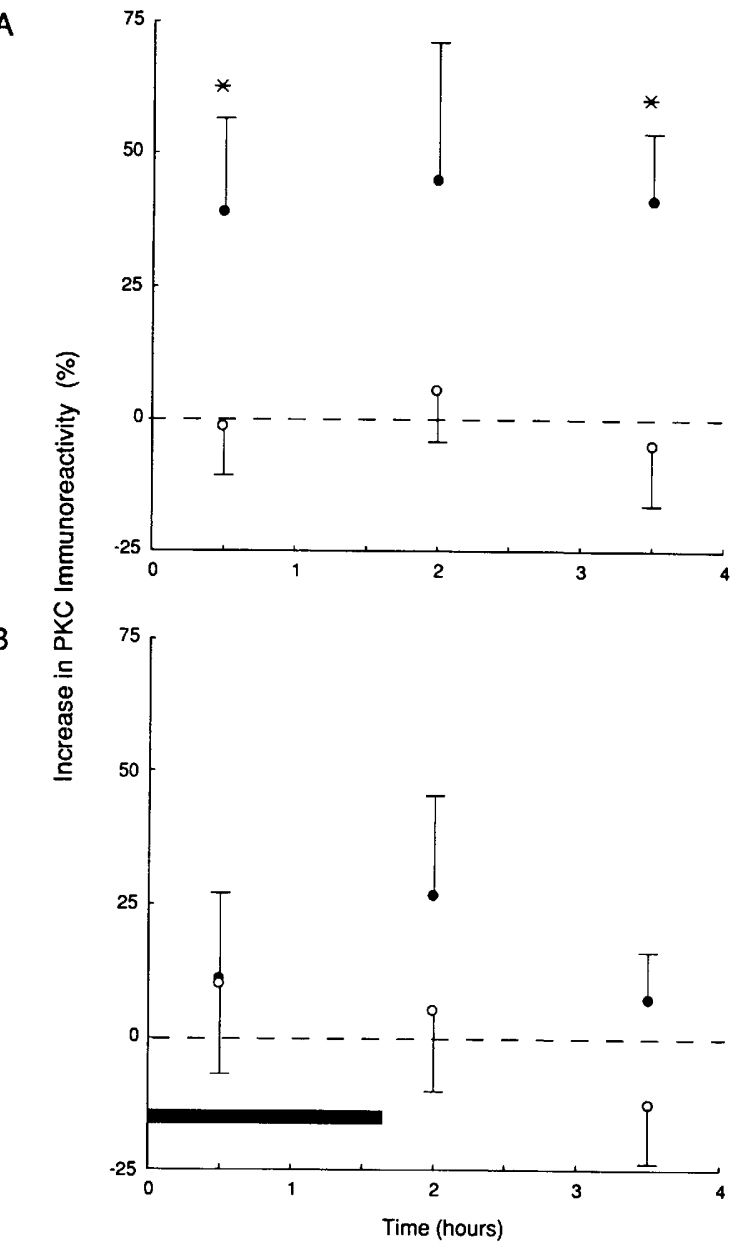

Figure 4: Quantitation of immunoblot experiments. Data are expressed as the percent change in particulate (O) or supernatant $(O)$ immunoreactivity for $A p l$ I (A) or Apl II (B) measured at the times indicated. The horizontal bar represents the time during which the isolated ganglia were exposed to $5-\mathrm{HT}(20 \mu \mathrm{M})$. Asterisks $\left(^{*}\right)$ indicate measurements in which a comparison between the experimental and control ganglia (paired $t$-test) reached a significance value of $P<0.05$. Values are mean \pm S.E.M.; $n=7-13$.

tions that we found to be specific for PKC (Sossin and Schwartz 1992), and the assay is performed in the presence of high concentrations of EGTA and the specific polypeptide inhibitor of cAMP-dependent protein kinase. Furthermore, in control experiments, approximately half of the constitutive activity was immunoprecipitated from either supernatant or pellet fractions by an affinity-purified antipeptide carboxy-terminal antibody to Apl II (Table 2). These results suggest that both isoforms of the kinase can be persistently activated by sensitizing stimuli, possibly through different mecha- nisms: Apl I through a persistent change in the balance between activators and inhibitors and Apl II through a post-translational modification of the enzyme that creates an autonomous enzyme.

\section{Discussion}

\section{BIOCHEMICAL EVIDENCE FOR AN INTERMEDIATE FORM OF MEMORY}

We suggest that PKC is involved in the maintenance of synaptic strength in a stage of memory intermediate between short-term facilitation and the modifications that underlie the consolidation of synaptic memory (Greenberg et al. 1987; Schwartz and Greenberg 1987; Bailey and Kandel 1993; Alberini et al. 1994). Furthermore, we propose that this form of memory appears to be biochemically separable from the other forms. Recent evidence in Aplysia supports the idea that longterm facilitation is independent of short-term facilitation: Producing changes in gene expression is sufficient to mediate long-term facilitation even if the modifications underlying short-term facilitation are blocked pharmacologically (Emptage and Carew 1993) or do not occur because the stimulus is spatially remote from synaptic terminals (Clark and Kandel 1993). We provide evidence that changes in gene expression are required for biochemical changes (e.g., activation of PKC) during an intermediate phase of memory (Fig. 2) and suggest that this may also be independent of shortterm facilitation. There is also physiological evidence for a separable intermediate form of synaptic facilitation in Aplysia that is sensitive to anisomycin (Ghirardi et al. 1994). Still further, we suggest that the changes in gene expression required for intermediate memory may be distinct from those required for long-term facilitation, as they are selectively blocked by cyproheptidine (Fig. 2; Emptage and Carew 1993).

There may be a correspondence at the molecular level between the separation of intermediateand long-term changes in Aplysia and similar phases identified in hippocampal neurons. Activation of PKC has been shown to be required for the maintenance of synaptic changes during long-term potentiation (LTP) in the hippocampus (Malinow et al. 1988; Wang and Feng 1992), whereas activation of PKA is required in CA1 neurons for a late phase of synaptic potentiation but not at earlier times (Frey et al. 1993; Huang and Kandel 1994). This suggests that in hippocampal neurons, an in-

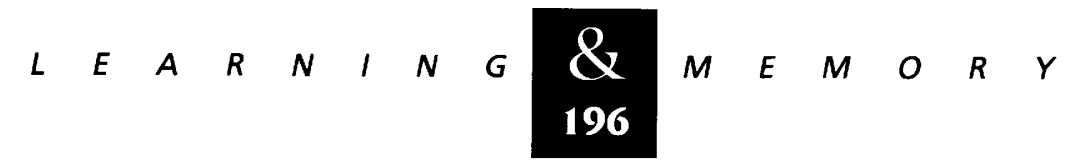



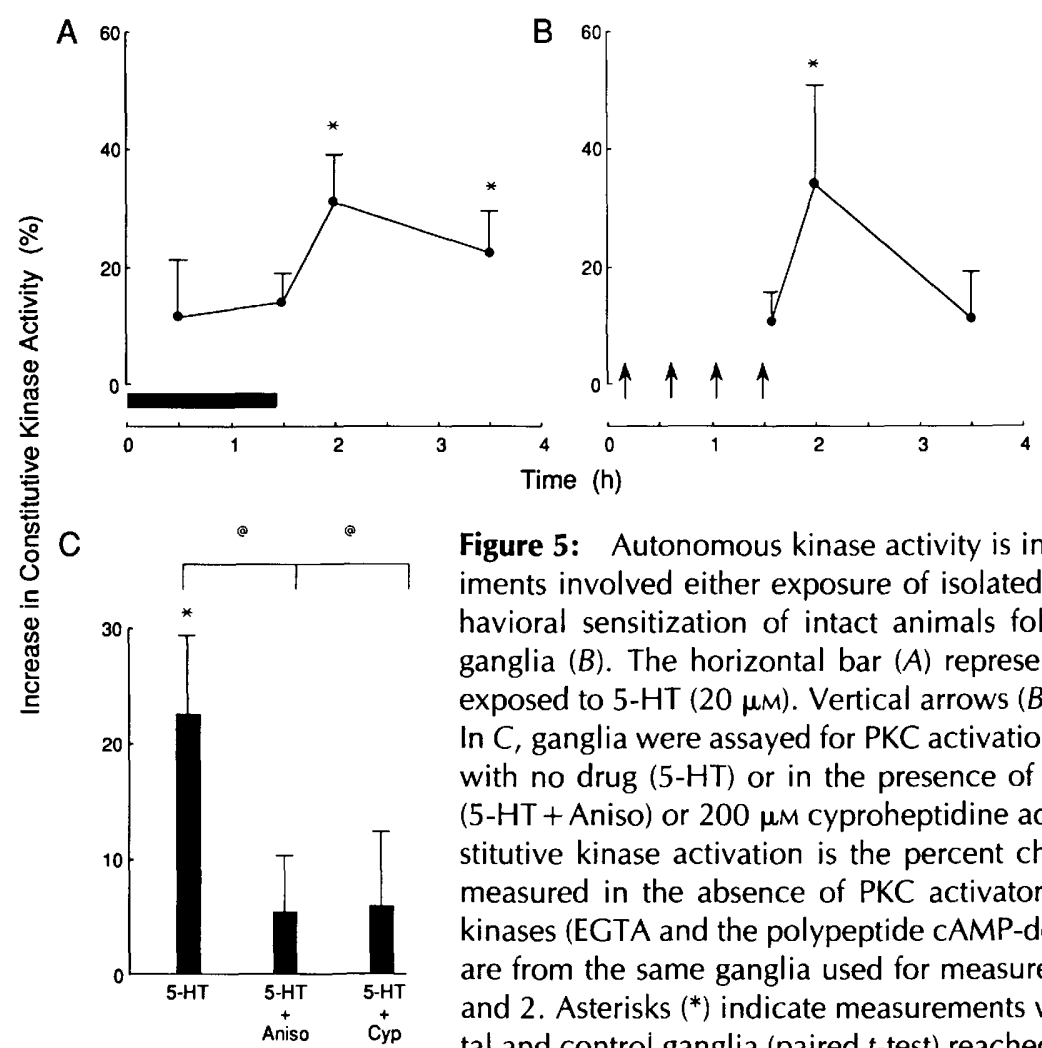

Figure 5: Autonomous kinase activity is increased during long-term facilitation. Experiments involved either exposure of isolated pleural-pedal ganglia to $5-\mathrm{HT}(A, C)$ or behavioral sensitization of intact animals followed later by dissection of pleural-pedal ganglia $(B)$. The horizontal bar $(A)$ represents the time during which the ganglia were exposed to $5-\mathrm{HT}(20 \mu \mathrm{M})$. Vertical arrows $(B)$ represent the time of each training episode. In C, ganglia were assayed for PKC activation 120 min after a 90-min application of 5-HT with no drug $(5-\mathrm{HT})$ or in the presence of $20 \mu \mathrm{M}$ anisomycin added $1 \mathrm{hr}$ before $5-\mathrm{HT}$ (5-HT + Aniso) or $200 \mu \mathrm{M}$ cyproheptidine added $30 \mathrm{~min}$ before 5-HT (5-HT + Cyp). Constitutive kinase activation is the percent change in particulate kinase activity that was measured in the absence of PKC activators but in the presence of inhibitors of other kinases (EGTA and the polypeptide CAMP-dependent protein kinase inhibitor). All values are from the same ganglia used for measurements of Apl I and Apl II activity in Figs. 1, and 2 . Asterisks $\left({ }^{*}\right)$ indicate measurements where a comparison between the experimental and control ganglia (paired t-test) reached a significance value of $P<0.05$. (@) Indication of where a comparison between treatment with $5-\mathrm{HT}$ and treatment with $5-\mathrm{HT}+\mathrm{drug}$ (Student's $t$-test) reached a significance value of $P<0.05$.

termediate memory dependent on activation of PKC can be separated from a later phase that is dependent on PKA. In Aplysia, activation of PKA has been shown to be sufficient for the induction of long-term structural changes in neurons (Nazif et al. 1991; Schacher et al. 1993). These observations suggest the possibility that a long-term program for structural changes is triggered by activating gene expression, predominantly through PKA, whereas PKC would play a more important role in the maintenance of synaptic changes during intermediate stages of memory.

Other biochemical changes occur during the development of long-term facilitation that may contribute to an intermediate phase of memory. There are changes in protein synthesis at 1 and 3 hr after application of 5-HT to isolated sensory neurons (Barzilai et al. 1989) that are analogous to the transitional (phase 2) and intermediate (phase 3) phases of PKC activation. Activation of ApC/ EBP, a transcription factor that is required for long-term facilitation, is maximal $2 \mathrm{hr}$ after application of 5-HT (Alberini et al. 1994) corresponding to the transitional phase.
The persistent activation of Apl I can be dissociated from its short-term activation. Most suggestions for the formation of a persistently active kinase have assumed that initial activation of the kinase coupled to an associated event (e.g., activation of a protease) or prolongation of the initial activation (e.g., resulting in more autophosphorylation) leads to a modification of the kinase that causes persistent activation (Lisman 1985; Schwartz and Greenberg 1987). Thus, the persistent activation might be expected to follow directly from the initial stimulation. In contrast, the persistent activation of Apl I appears not to depend directly on its short-term activation (Fig. 1). The persistent activation of PKA during long-term facilitation in Aplysia is also dependent on protein synthesis (Bergold et al. 1990) and thus may be separated from its short-term activation.

PHYSIOLOGICAL RELEVANCE OF PERSISTENT PKC ACTIVATION

Short-term activation of PKC by 5-HT leads to several physiological changes that are associated

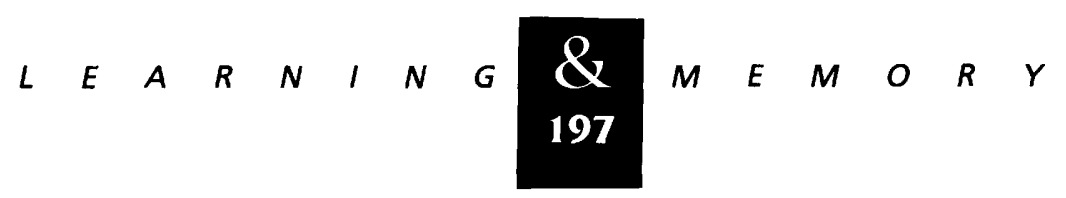


Sossin et al.

Table 2. Antibodies to Apl II, but not Apl I, remove autonomous PKC from extracts of control ganglia

\begin{tabular}{lcc}
\hline & \multicolumn{2}{c}{$\begin{array}{l}\text { Autonomous kinase activity } \\
\text { remaining in supernatant }\end{array}$} \\
\cline { 2 - 3 } Antibody & $\begin{array}{l}\text { particulate } \\
\text { fraction }\end{array}$ & $\begin{array}{l}\text { supernatant } \\
\text { fraction }\end{array}$ \\
\hline Apl I & $82 \pm 6$ & $110 \pm 5$ \\
Apl II & $52 \pm 6$ & $34 \pm 3$ \\
Apl I + Apl II & $56 \pm 4$ & $23 \pm 3$ \\
\hline
\end{tabular}

Saturating amounts of a polyclonal rabbit antibody to Apl I (Sossin et al. 1993), an equal amount of control polyclonal normal rabbit serum, an affinity-purified rabbit antibody to Apl II (Kruger et al. 1991), an equal amount of control rabbit IgG, a combination of the two antibodies, or a combination of the two controls were used to immunoprecipitate PKC activity from a supernatant fraction of nervous system or from a $1 \%$ octly- $\beta$ glucoside extract of a particulate fraction of nervous system. The antibodies were less efficient at immunoprecipitation in the presence of detergent (data not shown), and the percent immunoprecipitated from the particulate fraction should be taken as lower estimates. After precipitation, the resulting supernatants were assayed for the amount of remaining PKC activity. For each antibody, the amount of activity remaining in the appropriate control precipitation was set at $100 \%$.

with increases in synaptic strength. These include spike broadening (Sugita et al. 1992), increases in $\mathrm{Ca}^{2+}$ current (Braha et al. 1993), and a presumed increase in vesicle mobilization associated with the reversal of synaptic depression (Braha et al. 1990; Ghirardi et al. 1992). Cyproheptidine blocks several aspects of short-term facilitation, presumably by blocking the activation of PKC (Fig. 2) and partially blocking the activation of PKA (Mercer et al. 1991; Goldsmith and Abrams 1992). Persistent activation of PKC during an intermediate phase of memory presumably would lead to the continued presence of the same physiological changes mediated by PKC during short-term facilitation. This is an idea that can be tested by examining the effects of inhibitors of PKC on the facilitation of the EPSP that can be measured during this time period (Ghirardi et al. 1994). At the present time, the psychological and behavioral correlates of intermediate memory are difficult to examine empirically, but are the subject of interesting theoretical models (see, e.g., Baddeley and Hitch 1993; McClelland et al. 1994).

\section{MECHANISMS FOR PERSISTENT PKC ACTIVATION}

There were two measures of PKC activation that persist after long-term stimulation: (1) an increase in particulate Apl I activity and (2) an increase in constitutive or autonomous kinase activity. Changes in PKC activators or inhibitors resulting from changes in gene expression might explain the increase in particulate Apl I activity but not the increase in autonomous PKC activity. Conversely, proteolysis of the regulatory region of Apl I or Apl II could explain the increase in autonomous PKC activity but not the increase in particulate Apl I activity that still requires PKC activators. A mechanism involving proteolysis would be similar both to models for persistent PKC formation during LTP (Sacktor et al. 1993) and protein synthesis-dependent degradation of regulatory subunits of the cAMP-dependent protein kinase in Aplysia sensory neurons (Bergold et al. 1990; Hegde et al. 1993). A modification of Apl I (e.g., phosphorylation) that increases both its activity at basal levels of diacylglycerol and its activity without activators could explain both results. Phosphorylation of PKCs has been proposed to explain autonomous activation in the hippocampus (Klann et al. 1993).

\section{ACTIVATION OF APL II}

Apl II is transiently activated by long-term but not short-term stimulation protocols (Sossin and Schwartz 1992; Fig. 1). This is puzzling because the $\mathrm{Ca}^{2+}$-independent isoform might be expected to be activated by default under all conditions that stimulate the $\mathrm{Ca}^{2+}$-activated kinase: $\mathrm{Ca}^{2+}$-activated PKCs require both a lipid activator and $\mathrm{Ca}^{2+}$ ion, whereas $\mathrm{Ca}^{2+}$-independent PKCs require only a lipid activator. We have suggested that the presence of endogenous PKC inhibitors prevents Apl II from being activated during shortterm sensitization (Sossin and Schwartz 1994). A transient decrease in concentration of an inhibitor induced by long-term stimuli could explain the concomitant activation of both Apl I and Apl II shortly after the end of the long-term stimulus. Alternatively, an activator of Apl II, as yet unidentified, may be formed transiently by the prolonged stimulation that produces long-term sensitization.

\section{PERSISTENT PHOSPHORYLATION: A COMMON MECHANISM FOR SYNAPTIC MEMORY}

There are several similarities between activation of persistent phosphorylation during long-

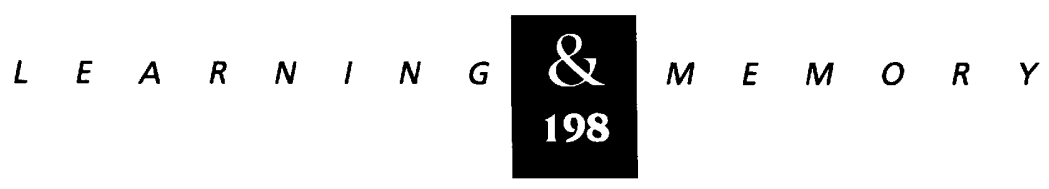


term facilitation in Aplysia and in LTP in vertebrates. During LTP of CA1 neurons, PKC activity is persistently enhanced (Klann et al. 1991, 1992; Gianotti et al. 1992; Sacktor et al. 1993), and this is associated with the formation of autonomous PKC (Klann et al. 1993). Particulate PKCs do not appear to increase after LTP in the CA1 region of the hippocampus (Sacktor et al. 1993; Klann et al. 1993), but persistent increases in particulate PKCs have been reported in other vertebrate learning paradigms and in other brain regions (Akers et al. 1986; Bank et al. 1989; Olds et al. 1989; Burchuladze et al. 1990; Olds and Alkon 1991).

Persistent protein phosphorylation is an important way to generate long-term changes in synaptic strength (Schwartz and Greenberg 1987). All three of the multifunctional protein kinases (PKA, calcium-calmodulin-dependent protein kinase II, and $\mathrm{PKC}$ ) can be activated in a persistent manner and by different molecular mechanisms (Greenberg et al. 1987; Kennedy 1989; Klann et al. 1992, 1993; Hanson and Schulman 1992; Fukunaga et al. 1993; Sacktor et al. 1993). Interestingly, it appears that different isoforms of PKC can be activated by different mechanisms (Klann et al. 1993; Sacktor et al. 1993; Dekker and Parker 1994). In the future it will be important to understand how these diverse ways of producing persistent kinases can be integrated into a sequential molecular mechanism for memory.

\section{Acknowledgments}

We thank Mark Klein and Vincent Castellucci for reading the manuscript critically. This work was supported by National Institutes of Health grant NS-29255 and National Institute of Mental Health grant MH-48850 to J.H.S. and Medical Research Council (MRC) of Canada grant MT-12046 to W.S. W.S. is an MRC of Canada scholar.

The publication costs of this article were defrayed in part by payment of page charges. This article must therefore be hereby marked "advertisement" in accordance with 18 USC section 1734 solely to indicate this fact.

\section{References}

Akers, R.F., D.M. Lovinger, P.A. Colley, D.J. Linden, and A. Routtenberg. 1986. Translocation of protein kinase $C$ activity may mediate hippocampal long-term potentiation. Science 231: $587-589$.

Alberini, C.M., M. Ghirardi, R. Metz, and E.R. Kandel. 1994. C/EBP is an immediate-early gene required for the consolidation of long-term facilitation in Aplysia. Cell 76: 1099-1114.
Baddeley, A.D. and G. Hitch. 1993. The recency effect: Implicit learning with explicit retrieval? Mem. Cognit. 21: 146-155.

Bailey, C.H. and E.R. Kandel. 1993. Structural changes accompanying memory storage. Annu. Rev. Physiol. 55: $397-426$.

Bank, B., J.J. LoTurco, and D.L. Alkon. 1989. Learning-induced activation of protein kinase C. A molecular memory trace. Mol. Neurobiol. 3: 55-70.

Barzilai, A., T.E. Kennedy, J.D. Sweatt, and E.R. Kandel. 1989. 5-HT modulates protein synthesis and the expression of specific proteins during long-term facilitation in Aplysia sensory neurons. Neuron 2: 1577-1586.

Bergold, P.J., J.D. Sweatt, I. Winicov, K.R. Weiss, E.R. Kandel, and J.H. Schwartz. 1990. Protein synthesis during acquisition of long-term facilitation is needed for the persistent loss of regulatory subunits of the Aplysia cAMP-dependent protein kinase. Proc. Natl. Acad. Sci. 87: 3788-3791.

Braha, O., N. Dale, B. Hochner, M. Klein, T.W. Abrams, and E.R. Kandel. 1990. Second messengers involved in the two processes of presynaptic facilitation that contribute to sensitization and dishabituation in Aplysia sensory neurons. Proc. Natl. Acad. Sci. 87: 2040-2044.

Braha, O., B. Edmonds, T. Sacktor, E.R. Kandel, and M. Klein. 1993. The contributions of protein kinase $A$ and protein kinase $\mathrm{C}$ to the actions of 5-HT on the L-type $\mathrm{Ca}^{2+}$ current of the sensory neurons in Aplysia. I. Neurosci. 13: $1839-1851$

Burchuladze, R., J. Potter, and S.P. Rose. 1990. Memory formation in the chick depends on membrane-bound protein kinase C. Brain Res. 535: 131-138.

Byrne, J.H., D.A. Baxter, D.V. Buonomano, L.J. Cleary, A. Eskin, J.R. Goldsmith, E. McClendon, F.A. Nazif, F. Noel, and K.P. Scholz. 1991. Neural and molecular bases of nonassociative and associative learning in Aplysia. Ann. N.Y. Acad. Sci. 627: 124-149.

Catterall, W.A., T. Scheuer, W. Thomsen, and S. Rossie. 1991. Structure and modulation of voltage-gated ion channels. Ann. N.Y. Acad. Sci. 625: 174-180.

Clark, G.A. and E.R. Kandel. 1993. Induction of long-term facilitation in Aplysia sensory neurons by local application of serotonin to remote synapses. Proc. Natl. Acad. Sci.

90: 11411-11415.

Dekker, L.V. and P. S. Parker. 1994. Protein kinase C: A question of specificity. Trends Biochem. Sci. 19: 73-77.

Eisenstadt, M., J.E. Goldman, E.R. Kandel, H. Koike, J. Koester, and J.H. Schwartz. 1973. Intrasomatic injection of radioactive precursors for studying transmitter synthesis in identified neurons of Aplysia. Proc. Natl. Acad. Sci. 70: $3371-3375$.

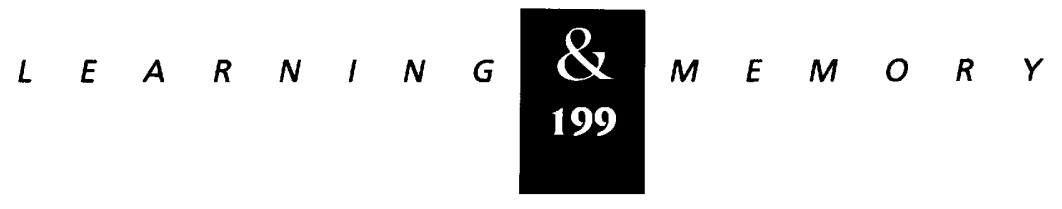




\section{Sossin et al.}

Emptage, N.J. and T.J. Carew. 1993. Long-term synaptic facilitation in the absence of short-term facilitation in Aplysia neurons. Science 262: 253-256.

Farley, J. and S. Auerbach. 1986. Protein kinase C activation induces conductance changes in Hermissenda photoreceptors like those seen in associative learning. Nature 319: 220-223.

Farley, J. and E. Schuman. 1991. Protein kinase C inhibitors prevent induction and continued expression of cell memory in Hermissenda type B photoreceptors. Proc. Natl. Acad. Sci. 88: 2016-2020.

Finch, D.M. and M.B. Jackson. 1990. Presynaptic enhancement of synaptic transmission in hippocampal cell cultures by phorbol esters. Brain Res. 518: 269-273.

Frey, U., Y.Y. Huang, and E.R. Kandel. 1993. Effects of CAMP simulate a late stage of LTP in hippocampal CA1 neurons. Science 260: 1661-1664.

Frost, W.N., V.F. Castellucci, R.D. Hawkins, and E.R. Kandel. 1985. Mono-synaptic connections made by the sensory neurons of the gill- and siphon-withdrawal reflex in Aplysia participate in the storage of long-term memory for sensitization. Proc. Natl. Acad. Sci. 88: 9021-9025.

Fukunaga, K., L. Stoppini, E. Miyamoto, and D. Muller. 1993. Long-term potentiation is associated with an increased activity of $\mathrm{Ca}^{2+} /$ calmodulin-dependent protein kinase II. J. Biol. Chem. 268: 7863-7867.

Ghirardi, M., O. Braha, B. Hochner, P.G. Montarolo, E.R. Kandel, and N. Dale. 1992. Roles of PKA and PKC in facilitation of evoked and spontaneous transmitter release at depressed and nondepressed synapses in Aplysia sensory neurons. Neuron 9: 479-489.

Ghirardi, M., P.G. Montarolo, and E.R. Kandel. 1994. A novel intermediate stage in the transition between short and long-term facilitation induced by $5-\mathrm{HT}$ in the sensory-to-motor Neuron synapse of Aplysia. Neuron (in press).

Gianotti, G., M.G. Nunzi, W.H. Gispen, and R. Coradetti. 1992. Phosphorylation of the presynaptic protein B-50 (GAP-43) is increased during electrically induced long-term potentiation. Neuron 8: 838-848.

Goldsmith, B.A. and T.W. Abrams. 1992. cAMP modulates multiple $\mathrm{K}+$ currents, increasing spike duration and excitability in Aplysia sensory neurons. Proc. Natl. Acad. Sci. 89: 11481-11485.

Greenberg, S.M., V.F. Castelluci, H. Bayley, and J.H. Schwartz. 1987. A molecular mechanism for long-term sensitization in Aplysia. Nature 329: 62-65.

Greengard, P., F. Valtorta, A.J. Czernik, and F. Benfenati. 1993. Synaptic vesicle phosphoproteins and regulation of synaptic function. Science 259: 780-785.

Hanson, P.I. and H. Schulman. 1992. Neuronal
$\mathrm{Ca}^{2+} /$ calmodulin-dependent protein kinases. Annu. Rev. Biochem. 61: 559-601

Hegde, A.N., A.L. Goldberg, and J.H. Schwartz. 1993. Regulatory subunits of CAMP-dependent protein kinases are degraded after conjugation to ubiquitin: A molecular mechanism underlying long-term synaptic plasticity. Proc. Natl. Acad. Sci. 90: 7436-4740.

Heidenrich K.A., S.P. Toledo, L.L. Brunton, M.J. Watson, S. Daniel-Issakani, and B. Strulovichi. 1990. Insulin-stimulated activity of a novel protein kinase C, PKC- $\epsilon$ in cultured fetal chick neurons. J. Biol. Chem. 265: 15076-15082.

Huang, Y.Y. and E.R. Kandel. 1994. Recruitment of long-lasting and protein kinase A-dependent long-term potentiation in the $\mathrm{CA} 1$ region of hippocampus requires repeated tetanization. Learn. Mem. 1: 74-82.

Kandel, E.R. and J.H. Schwartz. 1982. Molecular biology of learning: Modulation of transmitter release. Science 218: 433-443.

Kennedy, M.B. 1989. Regulation of brain type II $\mathrm{Ca}^{2+} /$ calmodulin-dependent protein kinase by autophosphorylation: $\mathrm{A} \mathrm{Ca}^{2+}$-triggered molecular switch. Cell 59: 777-787.

Kiley S.C. and S. Jaken. 1990. Activation of $\alpha$-protein kinase $C$ leads to association with a detergent-insoluble component. Mol. Endocrinol. 4: 59-67.

Klann, E., S.J. Chen, and J.D. Sweatt. 1991. Persistent protein kinase activation in the maintenance phase of long-term potentiation. J. Biol. Chem. 266: 24253-24256.

1992. Increased phosphorylation of a 17-kDa protein kinase $\mathrm{C}$ substrate (P17) in long-term potentiation. . Neurochem. 58: 1576-1579.

1993. Mechanism of protein kinase $C$ activation during the induction and maintenance of long-term potentiation probed using a selective peptide substrate. Proc. Natl. Acad. Sci. 90: 8337-8341.

Kruger, K.E., W.S. Sossin, T.C. Sacktor, P.J. Bergold, S. Beushausen, and J.H. Schwartz. 1991. Cloning and characterization of $\mathrm{Ca}^{2+}$-dependent and $\mathrm{Ca}^{2+}$-independent PKCs expressed in Aplysia sensory cells. J. Neurosci. 11: 2303-2313.

Kuhl, D., T.E. Kennedy, A. Barzilai, and E.R. Kandel. 1992. Long-term sensitization training in Aplysia leads to an increase in the expression of $\mathrm{BiP}$, the major protein chaperon of the ER. J. Cell Biol. 119: 1069-1076.

Leach, K.L. and D.M. Raben. 1993. Nuclear localization of protein kinase C. [Review]. Biochem. Soc. Trans. 21: 879-883.

Lisman, J.E. 1985. A mechanism for memory storage insensitive to molecular turnover: A bistable

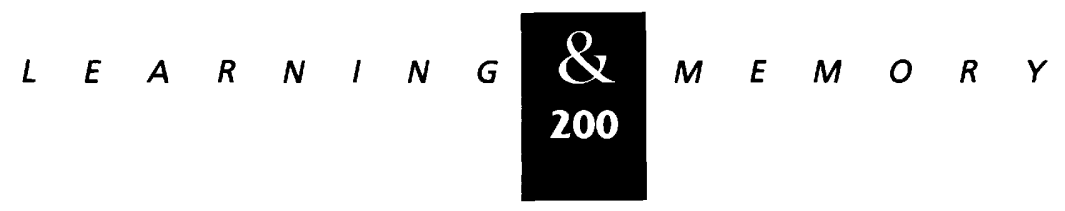


autophosphorylating kinase. Proc. Natl. Acad. of Sci. 82: 3055-3057.

Lovinger, D.M., K.L. Wong, K. Murakami, and A. Routtenberg. 1987. Protein kinase $C$ inhibitors eliminate hippocampal long-term potentiation. Brain Res.

436: 177-183.

Malenka, R.C., D.V. Madison, and R.A. Nicoll. 1986. Potentiation of synaptic transmission in the hippocampus by phorbol esters. Nature 321: 175-177.

Malenka, R.C., G.S. Ayoub, and R.A. Nicoll. 1987. Phorbol esters enhance transmitter release in rat hippocampal slices. Brain Res. 403: 198-203.

Malenka, R.C., J.A. Kauer, D.J. Perkel, M.D. Mauk, P.T. Kelly, R.A. Nicoll, and M.N. Waxman. 1989. An essential role for postsynaptic calmodulin and protein kinase activity in long-term potentiation. Nature 340: 554-557.

Malinow, R., D.V. Madison, and R.W. Tsien. 1988. Persistent protein kinase activity underlying long-term potentiation. Nature 335: 820-824.

McClelland, J.L., B.L. McNaughton, and R.C. O'Reilly. 1994. Why there are complementary learning systems in the hippocampus and neocortex: Insights from the successes and failures of connectionist models of learning and memory. Carnegie Mellon Univ. Tech. Rep. PDP.CNS.94.1.

McPhie, P.L., L.D. Matzel, J.L. Olds, D.S. Lester, A.M. Kazirian, and D.L. Alkon. 1993. Cell specificity of molecular changes during memory storage. J. Neurochem.

60: 646-651.

Mercer, A.R., N.J. Emptage, and T.J. Carew. 1991. Pharmacological dissociation of modulatory effects of serotonin in Aplysia sensory neurons. Science 254: 1811-1813.

Montarolo, P.G., P. Goelet, V.F. Castellucci, J. Morgan, E.R. Kandel, and S. Schacher. 1986. A critical period for macromolecular synthesis in long-term heterosynaptic facilitation in Aplysia. Science 234: 1249-1254.

Nazif, F.A., J.H. Byrne, and L.J. Cleary. 1991. cAMP induces long-term morphological changes in sensory neurons of Aplysia. Brain Res. 539: 324-327.

Nishizuka Y. 1992. Intracellular signalling by hydrolysis of phospholipids and activation of protein kinase C. Science 258: $607-614$.

Olds, J.L. and D.L. Alkon. 1991. A role for protein kinase C in associative learning. New Biol. 3: 27-35.

Olds, J.L., M.L. Anderson, D.L. McPhie, L.D. Staten, and D.L. Alkon. 1989. Imaging of memory-specific changes in the distribution of protein kinase $C$ in the hippocampus. Science 245: 866-869.

Sacktor, T.C. and J.H. Schwartz. 1990. Sensitizing stimuli cause translocation of protein kinase $C$ in Aplysia sensory neurons. Proc. Natl. Acad. Sci. 87: 2036-2039.

Sacktor, T.C., P. Osten, H. Valsamis, X. Jiang, M.U. Naik, and $E$. Sublette. 1993. Persistent activation of the zeta isoform of protein kinase $C$ in the maintenance of long-term potentiation. Proc. Natl. Acad. Sci. 90: 8342-8346.

Schacher, S., V.F. Castellucci, and E.R. Kandel. 1988. cAMP evokes long-term facilitation in Aplysia sensory neurons that requries new protein synthesis. Science 240: 1667-1669.

Schacher, S., E.R. Kandel, and P. Montarolo. 1993. cAMP and arachidonic acid simulate long-term structural and functional changes produced by neurotransmitters in Aplysia sensory neurons. Neuron 10: 1079-1088.

Scholtz, K.P. and J.H. Byrne. 1987. Long-term sensitization in Aplysia: Biophysical correlates in tail sensory neurons. Science 235: 685-687.

Schwartz, J.H. 1993. Cognitive kinases. Proc. Natl. Acad. Sci. 90: 8310-8313.

Schwartz, J.H. and S.M. Greenberg. 1987. Molecular mechanisms for memory: Second messenger induced modifications of protein kinases in nerve cells. Annu. Rev. Neurosci. 10: 459-476.

Schwartz, J.H. and M.E. Swanson. 1987. Dissection of tissues for characterizing nucleic acids from Aplysia: Isolation of the structural gene encoding calmodulin. Methods Enzymol. 139: 277-290.

Sossin, W.S. and J.H. Schwartz. 1992. Selective activation of $\mathrm{Ca}^{2+}$-activated PKCs in Aplysia neurons by 5-HT. I. Neurosci. 12: 1160-1168.

1994. Translocation of protein kinase Cs in Aplysia neurons: Evidence for complex regulation. Mol. Brain Res. 24: $210-218$.

Sossin, W.S., R. Diaz-Arrastia, and J.H. Schwartz. 1993. Characterization of two isoforms of protein kinase $C$ in the nervous system of Aplysia californica. J. Biol. Chem. 268: 5763-5768.

Sugita, S., J.R. Goldsmith, D.A. Baxter, and J.H. Byrne. 1992. Involvement of protein kinase $C$ in serotonin-induced spike broadening and synaptic facilitation in sensorimotor connections of Aplysia. I. Neurophys. 68: 643-651.

Sunayashiki, K.K., D.S. Lester, B.G. Schreurs, and D.L. Alkon. 1993. Associative learning potentiates protein kinase $C$ activation in synaptosomes of the rabbit hippocampus. Proc. Natl. Acad. Sci. 90: 4286-4289.

Sweatt, J.D. and E.R. Kandel. 1989. Persistent and transcriptionally-dependent increase in protein phosphorylation in long-term facilitation of Aplysia sensory neurons. Nature 339: 51-54.

Swope, S.L., S.J. Moss, C.D. Blackstone, and R.L. Huganir.

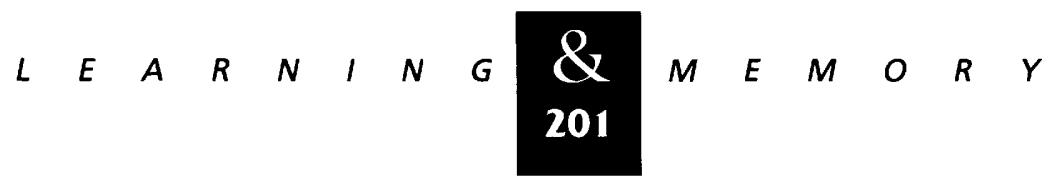




\section{Sossin et al.}

1992. Phosphorylation of ligand-gated ion channels: A possible mode of synaptic plasticity. FASEB J. 6: 2514-2253.

Thomas, T.P., R. Gopalakrishna, W.B. Anderson. 1987. Hormone- and tumor promoter-induced activation of membrane association of protein kinase $\mathrm{C}$ in intact cells. Methods Enzymol. 141: 399-411.

Wang, J.H. and D.P. Feng. 1992. Postsynaptic protein kinase $\mathrm{C}$ essential to induction and maintenance of long-term potentiation in the hippocampal CA1 region. Proc. Natl. Acad. Sci. 89: 2576-2580.

Received August 3, 1994; accepted in revised form September 15, 1994. 


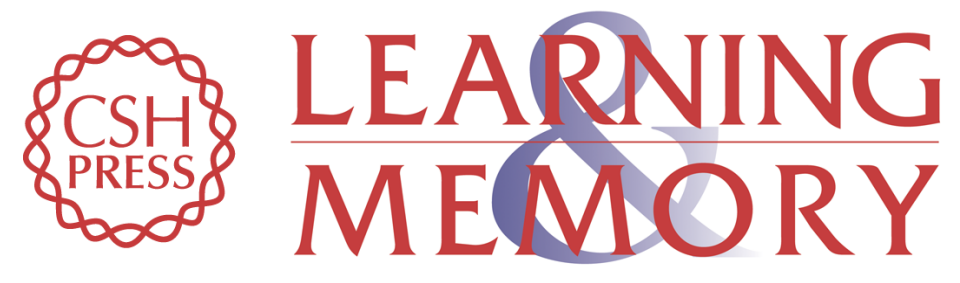

\section{Persistent activation of protein kinase $\mathrm{C}$ during the development of long-term facilitation in Aplysia.}

W S Sossin, T C Sacktor and J H Schwartz

Learn. Mem. 1994, 1:

Access the most recent version at doi:10.1101//m.1.3.189

References This article cites 70 articles, 35 of which can be accessed free at: http://learnmem.cshlp.org/content/1/3/189.full.html\#ref-list-1

License

Email Alerting Receive free email alerts when new articles cite this article - sign up in the box at the Service top right corner of the article or click here. 